\title{
14, 15-epoxygeranylgeraniol and extracts isolated from P terodon emarginatus Vog. fruits: antitumor activity on glioblastoma cells
}

\author{
Daiane Hansen $^{\mathrm{a}, \mathrm{b} *}$, Adriana Miti Nakahata ${ }^{\mathrm{c}}$, Mitsue Haraguchi ${ }^{\mathrm{b}}$, Oswaldo Keith Okamoto $^{\mathrm{c}}$, Edlayne Gonçalez ${ }^{\mathrm{b}}$ and \\ Antonio Alonso ${ }^{\mathrm{a}}$ \\ anstitute of Physics, University Federal of Goiás, Goiânia, 74001-970, GO, Brazil. \\ ${ }^{\mathrm{b}}$ Center of Animal Health, Biological Institute of São Paulo, 04014-002, SP, Brazil. \\ ${ }^{c}$ Department of Genetics, Biosciences Institute, University of São Paulo, 05508-090, SP, Brazil.
}

\section{ARTICLE INFO}

Article history:

Received on: 03/09/2012

Revised on: 14/09/2012

Accepted on: 20/09/2012

Available online: 28/09/2012

Key words:

14,15-epoxygeranylgeraniol, sucupira, Pterodon, antitumor, glioblastoma cells, medicinal plants

\begin{abstract}
Plant-derived substances have traditionally played important roles in the treatment of human diseases, including of great significance to cancer therapy. Plants of the genus Pterodon (Fabaceae, Leguminosae), commonly known as 'sucupira', are disseminated throughout the central region of Brazil and have been used frequently in popular medicine. In recent years, interest in these plants has increased considerably. The biological effects of their extracts and pure metabolites have been investigated in several experimental models in vivo and in vitro. Until the present day, the antitumor effect of Pterodon plants on brain tumors is unknown. Therefore, the aim of this work was to investigate the action of $P$. emarginatus Vogel extracts and its fractions on glioblastoma cells. The hexane (HE), dichloromethane (DE) and ethanol (EE) extracts were obtained from seeds powder in each solvent. The diterpene 14,15-epoxygeranylgeraniol was obtained from HE fractionation. For tumorigenic assays, the extracts and fractions were added to U87MG, a human glioblastoma cells line. The cell viability assay showed that the proliferation of U87MG was inhibited by both extracts and the 14,15epoxygeranylgeraniol. Further trials in vivo will help to confirm these results, and may contribute to generate natural compounds for the treatment of this type of cancer.
\end{abstract}

\section{INTRODUCTION}

Human beings have used some plant constituents for centuries, e.g., to prepare poisonous spearheads for warfare and hunting. The plants make use sophisticated signaling mechanisms and an elaborate chemical arsenal of deadly weapons such as terpenes to poison the soil to inhibit competitors, and alkaloids which make them unpalatable to insects and predators. Plantderived substances have traditionally played important roles in the treatment of human diseases, including of great significance to cancer therapy (Mans et al., 2000). Plant of the genus Pterodon

\footnotetext{
* Corresponding Author

Dr. Daiane Hansen, Center of Animal Health, Biological Institute of São Paulo, Avenida Conselheiro Rodrigues Alves, 1252, Vila Mariana, 04014-002, São Paulo, SP, Brazil.
}

(Fabaceae, Leguminosae), commonly known as 'sucupira' or 'faveira', comprises four native species: Pterodon abruptus Benth., Pterodon apparicioi Pedersoli., Pterodon polygalaeflorus Benth. and Pterodon emarginatus Vogel. synonym Pterodon pubescens Benth. (Carvalho, 2004). These genus are disseminated throughout the central region of Brazil and have been used frequently in popular medicine for its anti-rheumatic (Sabino et al., 1999; Coelho et al., 2004), analgesic (Spindola et al., 2011; Galceran et al., 2011) and anti-inflammatory (Dutra et al., 2009; Moraes et al., 2011) properties. In recent years, interest in these plants has increased considerably and, the biological effects of different phytoextracts and pure metabolites have been investigated in several experimental models in vivo and in vitro (Hansen et al., 2010). 
The investigations on the pharmacological properties of 'sucupira' surpass those of its anti-inflammatory and antirheumatic activities. The literature describes the presences of flavonoids, diterpenes, steroids, besides proteins from this genus (Hansen et al., 2010). The interest in the Pterodon genus began when Mors et al. (1967) isolated the geranylgeraniol and 14,15epoxygeranylgeraniol by hexane extraction of the essential oil from fruits of $P$. pubescens fruit essencial oil with hexane, showing the chemoprophylactic effect on schistosomiasis (Mors et al., 1966; 1967). The geranylgeraniol obtained of this plant presented antiplatelet (Calixto et al., 2007) and anti-Trypanosoma cruzi action with effect on proliferation of epimastogotes and trypomastigotes (Menna-Barreto et al., 2008). Spindola et al. (2010) evaluated the contribution of geranylgeraniol in the antinociceptive activity of the crude extracts from seeds of $P$. pubescens.

Related to antitumor activity of Pterodon genus, until now, little has been investigated. Some subfractions from crude ethanolic extract and the diterpene vouacapan-6 $\alpha, 7 \beta, 14 \beta, 19$ tetraol of seeds from $P$. pubescens have presented effect on human melanoma cells (Vieira et al., 2008) and furanoditerpenes have presented action in prostate cells (Spindola et al., 2009). In recent study, a terpenic subfraction presenting a furane diterpene, induced apoptosis of K562 leukemic cells (Pereira et al., 2011). In relation to $P$. polygalaeflorus species, the antiproliferative effect on human cancer cells was studied by Euzébio et al., (2009).

Until the present day, the effects of the Pterodon extract or metabolites on glioblastoma cells obtained from brain tumors are unknown. The highest-grade malignant astrocytoma, glioblastoma (GBM), is the most common and the major lethal type of tumor in the central nervous system, leading to a mean survival time of approximately 16 months after removal of tumor and radiotherapy (Valente et al., 2009). This discouraging prognosis is due to both the infiltrative nature of the tumor and the resistance of tumor cells to cytotoxic treatments (Omuro and Delattre, 2007; Dent et al., 2009; Agarwal et al., 2011).

The results reported here shows the action of extracts and of the diterpene 14,15-epoxygeranylgeraniol obtained from $P$. emarginatus fruits on proliferation of U87MG human glioblastoma cells line.

\section{MATERIALS AND METHODS}

\section{Plant Material}

The dry fruits were collected in the Cerrado region of the municipality of Urutaí, Goiás State, Brazil (17³9'3.3', S/ 48 14 '5.6" W), on August 2009. The plant was identified for botanic at the Botanic Institute Herbarium of São Paulo and a voucher specimen was deposited at the Biological Institute of São Paulo, under number DH2009/001.

\section{Hexane, Dichloromethane and Ethanol extracts}

The powdered dry fruits $(150 \mathrm{~g})$ were exhaustively macerated with hexane, dichloromethane and 92\% ethanol, successively. After extraction, the solvent was concentrated by rotator evaporation under reduced pressure yielding the hexane extract HE (34.6\%), dichloromethane extract DE (16.6\%) and ethanol extract EE (2.4\%).

The thin layer chromatography (TLC) and the UV spectroscopy were employed to characterize chemical skeletons, presenting compounds of terpene nature. The extracts were analyzed according its $R_{\mathrm{f}}$ (retention factor) on TLC, using silica gel $60 \mathrm{~F}_{254}$ Merck as stationary phase, hexane/ethyl acetate solution $(2: 1, \mathrm{v} / \mathrm{v})$ as moving phase and was revealed with vanillin $/ \mathrm{H}_{2} \mathrm{SO}_{4}$ at $100^{\circ} \mathrm{C}$.

\section{Hexanic extract fractionation $(\mathrm{C} 1)$}

The HE (30 g) was fractionated using column chromatography packed with silica gel 60 Merck KGaA (Darmstadt, Germany) and eluted with hexane and ethyl acetate, increasing order of polarity (fractions $\mathrm{Cl}_{1}$ to $\mathrm{C}_{40}$ ). The fractions were monitored by TLC employing a plastic plate impregnated with silica gel $60 \mathrm{G} \mathrm{F}_{254}$ Merck $\mathrm{KGaA}$ (Darmstadt, Germany), developed with hexane/ethyl acetate solution (2:1, v/v) and revealed with vanillin/ $\mathrm{H}_{2} \mathrm{SO}_{4}$ at $100^{\circ} \mathrm{C}$.

\section{Isolation and characterization of compound}

Based on TLC dates, the fraction $\mathrm{Cl}_{13}(290 \mathrm{mg})$ resultant of chromatography $\mathrm{C} 1$, was fractionated in a new column chromatography (C2) with the same stationary phase as $\mathrm{C} 1$ and was eluted with hexane and gradients of hexane/ethyl acetate solution $(95: 5 \mathrm{v} / \mathrm{v})$ up to $35 \%$ of ethyl acetate. The fractions were analyzed according its $R_{\mathrm{f}}$ on TLC, using the same stationary and moving phases as used in $\mathrm{C} 1$.

The identification of the compounds was carried out using proton $\left({ }^{1} \mathrm{H}-\mathrm{NMR}\right)$ and carbon nuclear magnetic resonance $\left({ }^{13} \mathrm{C}-\mathrm{NMR}\right)$. All spectra were recorded on a Bruker DPX300 spectrometer, operating at $300 \mathrm{MHz}$.

\section{Cell culture}

The U87MG human glioblastoma cancer cell line was kindly provided by Dr. Suely K. N. Marie from the Laboratory of Medical Investigation (LIM15) at the University of São Paulo. Cells were maintained in Dulbecco's-modified Eagle's MediumLow Glucose (DMEM-LG, Invitrogen), supplemented with $2 \mathrm{mM}$ L-glutamine, $10 \%$ bovine fetal serum, $100 \mathrm{U} / \mathrm{mL}$ penicillin, and $100 \mu \mathrm{g} / \mathrm{mL}$ streptomycin, in a humidified atmosphere at $37^{\circ} \mathrm{C}$ with $5 \% \mathrm{CO}_{2}$.

\section{Cell viability assay}

The effect of the extracts HE and its fractions, DE and $\mathrm{EE}$ on the viability of U87MG glioblastoma cells line was determined using a MTT-based assay (Carimichael et al., 1987). Briefly, exponential-phase cells were collected and transferred to a microtiter plate $\left(10^{3}\right.$ cells $\left./ 0.1 \mathrm{ml}\right)$. The cells were then incubated for 24,48 and 72 hs with various concentrations of the extracts and HE fractions. After incubation, $0.1 \mathrm{mg}$ MTT (Sigma, St. Louis, MO, USA) was added to each well, and the cells were 
incubated at $37^{\circ} \mathrm{C}$ for $2 \mathrm{~h}$. Then, the medium was carefully removed and added isopropanol to each well to dissolve formazan crystals. After 30 minutes of incubation at $37^{\circ} \mathrm{C}$, the plates were read immediately at $620 \mathrm{~nm}$ on a Packard SpectraCount microplate reader. The percentage of cell viability was calculated based on the following formula: mean value of (control group - treated group/control group) $\mathrm{x} 100 \%$. All results were assessed in triplicate for each concentration.

\section{Calculations and statistical analysis}

Cell viability experiments results were expressed as the percentage cell viability of control (untreated cells). All results were submitted to one way analysis of variance (ANOVA) with repeated measurements. The inhibitory concentration value $\left(\mathrm{IC}_{50}\right)$ was derived from a nonlinear regression model (curve fit) based on sigmoidal dose response curve and computed using GraphPad Prism, version 5.00 for Windows, GraphPad Software, San Diego, CA.

All assays were performed in triplicate.

\section{RESULTS AND DISCUSSION}

The preliminary results achieved by cell viability assay indicated that the crude hexane (HE), dichloromethane (DE) and ethanol extracts (EE) from $P$. emarginatus Vogel fruits inhibited at least $50 \%$ of the proliferation of U87MG human glioblastoma cells after 48 and 72 hours of incubation in the concentration of 10 $\mathrm{mg} / \mathrm{ml}$ (Fig. 1a and 1c). After 24 hours of incubation, the inhibition wasn't significant, as shown in Fig. 1a. Given these initial results, we decided investigated the HE in a first moment. Thus, the phytochemical study of the HE presented compounds of terpene nature; the TLC shows an intense spot with $R_{\mathrm{f}} 0.35$, which was also predominant in $\mathrm{C}_{13}, \mathrm{C} 2_{120}$ and neighboring fractions (Fig. 2). The NMR spectra through its carbon and hydrogen chemical shifts indicate that the molecule corresponding to $\mathrm{C} 2_{120}$ fraction is the diterpene 14,15-epoxygeranylgeraniol (Fig. 3), previously isolated for Mors et al. (1967).

To perform the cell viability assay to the fractions obtained from HE, U87MG cells were treated with $10^{-3}$ to $10^{3}$ $\mu \mathrm{g} / \mathrm{ml}$ of the $\mathrm{C} 1_{13}$ and $\mathrm{C} 2_{120}$ samples and incubated for 24, 48 and 72 hours. The calculated $\mathrm{IC}_{50}$ values of $\mathrm{HE}, \mathrm{C} 1_{13}$ and $\mathrm{C} 2_{120}$ fractions after 72 hours of incubation were $0.031,4.622$ and 9.706 $\mu \mathrm{g} / \mathrm{ml}$, and were obtained from the dose-response curve shown in Fig. 4a, 4b and 4c, respectively.

Natural product derived drugs constitute a vast majority of the chemotherapeutic agents currently in use for all types of cancers (Baker et al., 2007). Preliminary testing of antitumoral activity of $P$. emarginatus extracts and 14,15epoxygeranylgeraniol on glioblastoma cells presented promising results and the continuation of these studies, in additional trials in vivo, could contribute to generate new bioactive molecules or chemotherapeutic agents for this type of cancer. a

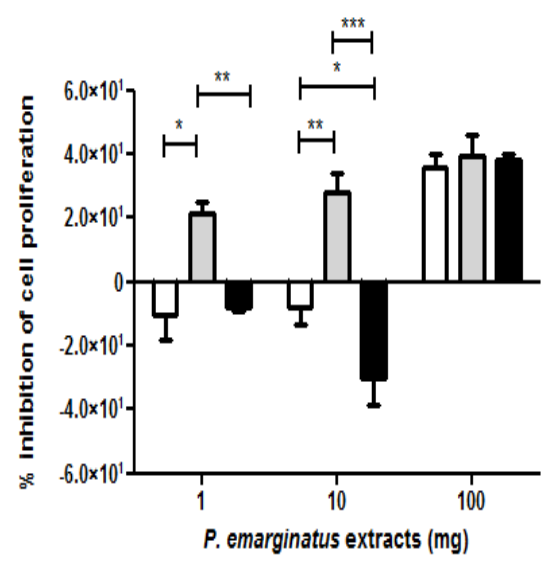

24 hours

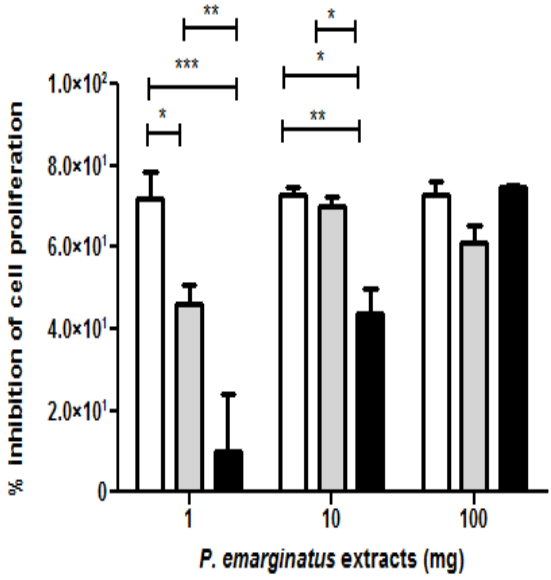

C

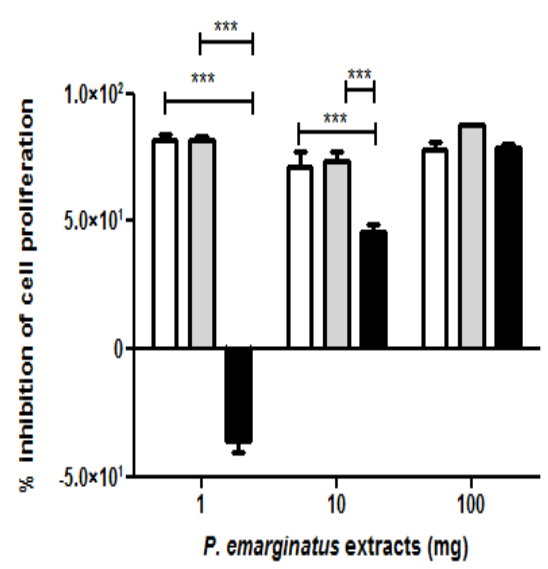

Fig. 1: Anticancer activity of $\boldsymbol{P}$. emarginatus extracts. The figure expressed the proliferation inhibition of U87MG human glioblastoma cells after incubation with HE, DE and EE crude extract in (a) 24 hours, (b) 48 hours, (c) 72 hours of the exposure. (*) $P \leq 0.05,(* *) P \leq 0.01,(* *) P \leq 0.001$ compared with corresponding control values (untreated cells). 


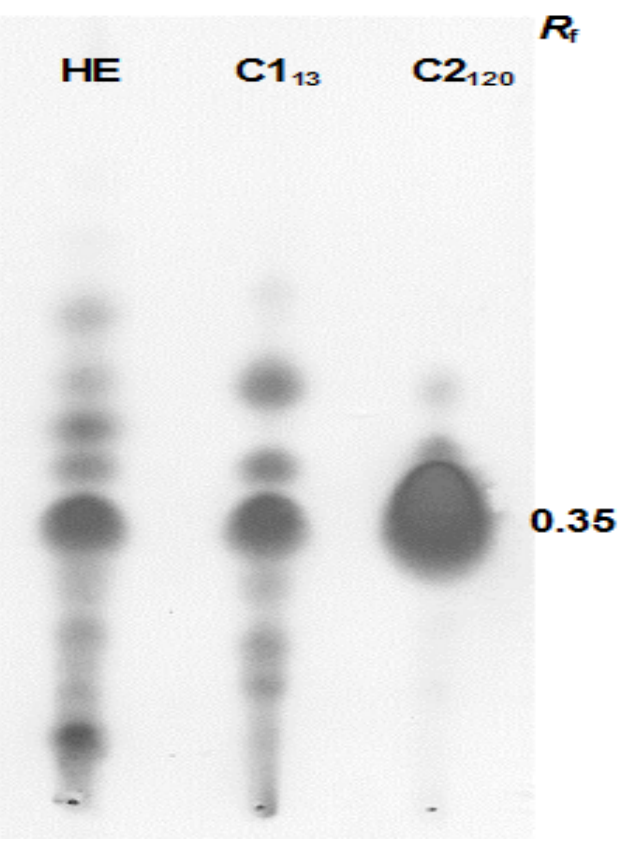

Fig. 2: Chromatogram on TLC of the hexane extract and its fractions. The TLC shows an intense spot with $R_{\mathrm{f}} 0.35$, which remained predominant after fractionation. HE: hexanic extract; $\mathrm{Cl}_{13}$ : fraction 13 from chromatography 1 and $\mathrm{C} 2_{120}$ : fraction 120 from chromatography 2 .

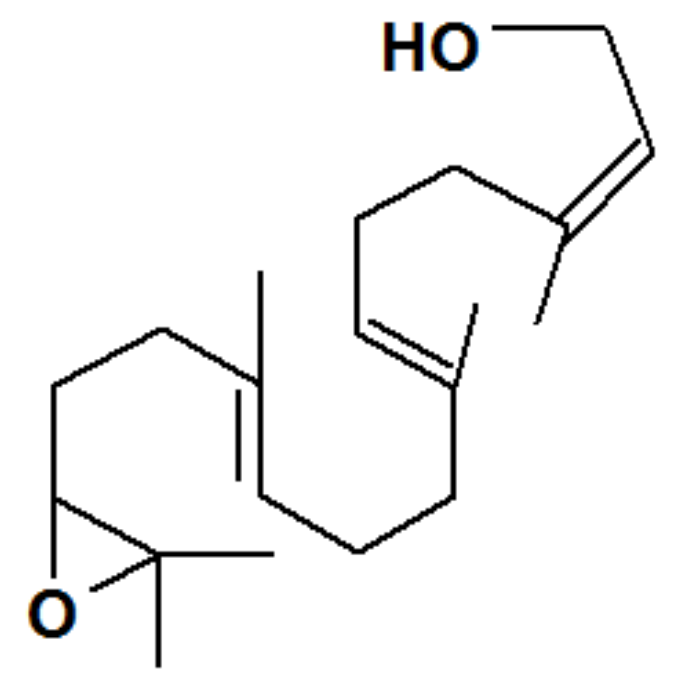

Fig. 3: Chemical structure of 14,15-epoxygeranylgeraniol. The NMR spectra through its carbon and hydrogen chemical shifts indicate that the molecule corresponding to $\mathrm{C}_{120}$ is the diterpene previously isolated for Mors et al. (1967). a

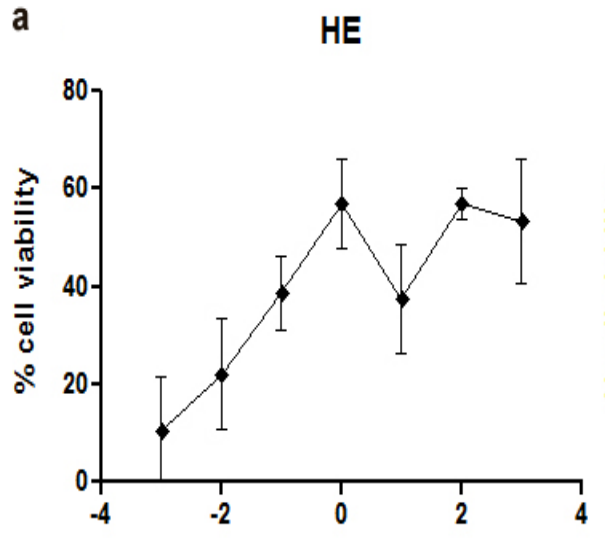

$\log$ concentration $(\mu \mathrm{g} / \mathrm{mL})$ b

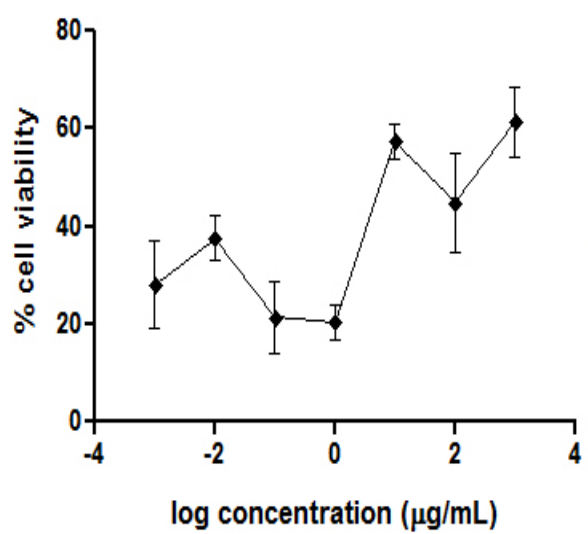

C

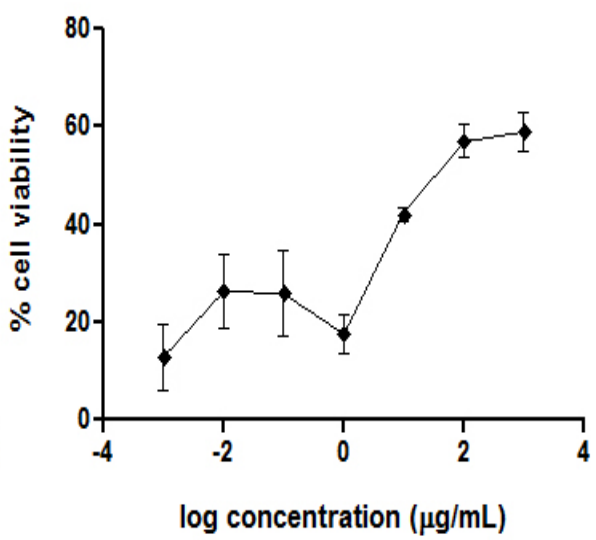

Fig. 4: Cell viability test of $\boldsymbol{P}$. emarginatus $\mathrm{HE}$ and its fractions. Dose-response curve of U87MG human glioblastoma cells following 72 hours exposure to (a) $\mathrm{HE}$, (b) $\mathrm{Cl}_{13}$ and (c) $\mathrm{C}_{2120}$. Cell viability was achieved by the MTT assay and expressed as percentage of untreated cells. 


\section{CONCLUSION}

The $P$. emarginatus extracts, hexane (HE), dichloromethane (DE) and ethanol (EE) and, the diterpene 14,15epoxygeranylgeraniol, obtained from $\mathrm{HE}$ fractionation, showed inhibited the U87MG glioblastoma cells proliferation in tumorigenic assays, as cell viability.

\section{ACKNOWLEDGMENTS}

The authors thanks the RMN Laboratory team of Chemistry Institute of University Federal of Goiás by RMN spectra and are grateful to CAPES/PNPD (PNPD0037087) and CNPq (UNIVERSAL 480021/2008-2) for financial support.

The authors declare no conflict of interest.

\section{REFERENCES}

Agarwal S., Sane R., Oberoi R., Ohlfest J.R., Elmquist W.F. Delivery of molecularly target therapy to malignant glioma, a disease of the whole brain. Expert. Rev. Mol. Med. 2011; 13:1-27.

Baker D.D., Chu M., Oza U., Rajgarhia V. The value of natural products to future pharmaceutical discovery. Nat. Prod. Rep. 2007; 24:1225-1244

Calixto N.O., Costa e Silva M.C., Gayer C.R., Coelho M.G., Paes M.C., Todeschini A.R. Antiplatelet activity of geranylgeraniol isolated from Pterodon pubescens fruit oil is mediated by inhibition of cyclooxigenase-1. Planta Med. 2007; 73:480-483.

Carimichael J., Degraff W.G., Gazdar A.F., Minna J.D., Mitchell J.B. Evaluation of a tetrazolium-based semiautomated colorimetric assay: assessment of chemosensitivity testing. Cancer Res. 1987; 47:936-942.

Carvalho, J.C.T. (2004). Sucupira, Pterodon emarginatus Vog. In: Carvalho JCT (ed). Fitoterápicos anti-inflamatórios - aspectos químicos, farmacológicos e aplicações terapêuticas (pp: 383). Ribeirão Preto: Tecmed.

Coelho M.G., Sabino K.C., Dalmau S.R. Immunomodulatory effects of sucupira (Pterodon pubescens) seed infusion on collageninduced arthritis. Clin. Exp. Rheumatol. 2004; 22:213-218.

Dent P., Yacoub A., Park M., Sarkar D., Shah K., Curiel D.T., Grant S. Searching for a cure: gene therapy for glioblastoma. Cancer Biol. Ther. 2008; 7:1335-1340.

Dutra R.C., Fava M.B., Alves C.C., Ferreira A.P., Barbosa N.R. Antiulcerogenic and anti-inflammatory activities of the essential oil from Pterodon emarginatus seeds. J. Pharm. Pharmacol. 2009; 61:243-250.

Euzébio F.P.G., dos Santos F.J.L., Piló-Veloso D., Ruiz A.L.T.G., Carvalho J.E., Ferreira-Alves D.L., de Fátima A. Effect of $6 \alpha$, $7 \beta$-dihydroxyvouacapan-17 $\beta$-oic acid and its lactone derivatives on the growth of human cancer cells. Bioorg. Chem. 2009; 37:96-100.

Galceran C.B., Sertie J.A.A., Lima C.S., Carvalho J.C.T. Antiinflammatory and analgesic effects of $6 \alpha, 7 \beta$-dihydroxy-vouacapan-17ßoic acid isolated from Pterodon emarginatus Vog. fruits. Inflammopharmacol. 2011; 19:139-143.

Hansen D., Haraguchi M., Alonso A. Pharmaceutical properties of 'sucupira' (Pterodon spp.). Brazilian Journal of Pharmaceutical Sciences 2010; 46:607-616.

Mans D.R.A., Rocha A.B., Schwartsmann G. Anti-Cancer Drug
Discovery and Development in Brazil: Targeted Plant Collection as a Rational Strategy to Acquire Candidate Anti-Cancer Compounds. The Oncologist 2000; 5:185-198.

Menna-Barreto R.F.S., Laranja G.A.T., Silva M.C.C., Coelho M.G.P., Paes M.C., Oliveira M.M., Castro S.L. Anti-Trypanosoma cruzi activity of Pterodon pubescens seed oil: geranylgeraniol as the major bioactive component. Parasitol. Res. 2000; 103:111-117.

Moraes W.F., Galdino P.M., Nascimento M.V.M., Vanderlinde F.A., Bara M.T.F., Costa E.A., de Paula J.R. Triterpenes involved in the anti-inflammatory effect of ethanolic extract of Pterodon emarginatus Vogel stem bark. J. Nat. Med. 2011; 66:202-207.

Mors W.B., Pellegrino J., dos Santos Filho M.F. Ação profilática do óleo dos frutos de Sucupira-Branca, Pterodon pubescens Benth, contra a infecção pelo Schistosoma mansoni. An. Acad. Bras. Ciênc. suppl. 1966; 38:325-330.

Mors W.B., Santos M.F., Monteiro M.B. Chemoprophylactic Agent in Schistosomiasis: 14,15-epoxygeranylgeraniol. Science 1967; 3791:950-951.

Omuro A.M., Delattre J.Y. Editorial: What is new in the treatment of gliomas? Curr. Opin. Neurol. 2007; 20:704-707.

Pereira M.F., Martino T., Dalmau S.R., Albano R.M., Férézou J.P., Costa S.S., Coelho M.G., Sabino K.G. Terpenic subfraction of Pterodon pubescens induces apoptosis of K562 leukemic cells by modulating gene expression. Oncol. Rep. 2011; 25:215-221.

Sabino K.C., Castro F.A., Oliveira J.C., Dalmau S.R., Coelho M.G. Successful treatment of collagen-induced arthritis in mice with a hydroalcohol extract of seeds of Pterodon pubescens. Phytother. Res. 1999; 13:613-615.

Spindola H.M., Carvalho J.E., Ruiz A.L.T.G., Rodrigues R.A.F., Denny C., Sousa I.M.O., Tamashiro J.Y., Foglio M.A. Furanoditerpenes from Pterodon pubescens Benth with selective in vitro anticancer activity for prostate cell line. J. Braz. Chem. Soc. 2009; 20:569575 .

Spindola H.M., Servat L., Denny C., Rodrigues R.A., Eberlin M.N., Cabral E., Sousa I.M., Tamashiro J.Y., Carvalho J.E., Foglio M.A. Antinociceptive effect of geranylgeraniol and 6alpha,7betadihydroxyvouacapan-17beta-oate methyl ester isolated from Pterodon pubescens Benth. BMC Pharmacol. 2010; 10:1

Spindola H.M., Servat L., Rodrigues R.A.F., Sousa I.M.O., Carvalho J.E., Foglio M.A. Geranylgeraniol and $6 \alpha, 7 \beta$-dihydroxyvouacapan-17 $\beta$-oate methyl ester isolated from Pterodon pubescens Benth.: Further investigation on the antinociceptive mechanisms of action. European Journal of Pharmacology 2011; 656:45-51.

Valente V., Teixeira S.A., Neder L., Okamoto O.K., Oba-Shinjo S.M., Marie S.K.N., Scrideli C.A., Paçó-Larson M.L., Carlotti Jr. C.G. Selection of suitable housekeeping genes for expression analysis in glioblastoma using quantitative RT-PCR. BMC Molecular Biology 2009; $10 \cdot 1-11$

Vieira C.R., Marques M.F., Soares P.R., Matsuda L., de Oliveira C.M.A., Kato L., da Silva C.C., Guillo L.A. Antiproliferative activity of Pterodon pubescens Benth. seed oil and its active principle on human melanoma cells. Phytomedicine 2008; 15:528-532.

\section{How to cite this article:}

Daiane Hansen, Adriana Miti Nakahata, Mitsue Haraguchi, Oswaldo Keith Okamoto, Edlayne Gonçalez and Antonio Alonso. .

14, 15-epoxygeranylgeraniol and extracts isolated from Pterodon emarginatus Vog. fruits: antitumor activity on glioblastoma cells. J App Pharm Sci. 2012; 2(9): 020-024. 